\title{
Ethics of Artificial Insemination: An Islamic Perspective
}

\author{
I. Sharmin, MA1; B.N. Rusli, PhD1; B.S. Ab Rani, FDSRCS1; B.M.N. Hanapi, PhD² \\ School of Dental Sciences ${ }^{1}$ and School of Health Sciences ${ }^{2}$ \\ University Science Malaysia \\ Kelantan, Malaysia
}

\begin{abstract}
:
This paper aims to address ethical issues related to the assisted reproductive technology method of artificial insemination (AI) from the Islamic perspective. Our evaluation suggests that the Islamic ethical viewpoint of AI is rational, comprehensive, and aims at the greatest good of mankind.
\end{abstract}

Key words: Artificial insemination, assisted reproductive technology, Islam, ethics, Sharia.

Introduction

A rtificial insemination (AI) is a technique in which sperms are placed in the female reproductive tract (uterus) by mechanical methods that precludes sexual ejaculation into the woman's vagina. ${ }^{1}$

About $10 \%$ of all married couples are incapable of conceiving and having a child. of these, $40 \%$ are due to male infertility. ${ }^{2}$ Male infertility can result from (a) inability to produce any sperm (azoospermia); (b) the production of too few sperms to make impregnation likely (oligospermia); (c) the production of an adequate number of sperm but the sperm not being sufficiently motile to make their way past the vaginal canal and through the fallopian tubes. As a result, their chances of reaching and penetrating an ovum are diminished; (d) neurological conditions that make ejaculation impossible; (e) impotence due to diseases such as diabetes mellitus. ${ }^{3}$ In these circumstances, AI can help the male partner overcome childlessness.

Female infertility can result from (a) a vaginal

Correspondence should be directed to

Rusli Bin Nordin

School of Dental Sciences, University Science Malaysia, 16150 Kubang Kerian, Kelantan, Malaysia

Fax: +6-09-7642026

E-mail: ruslinordin@yahoo.com environment that is biochemically inhospitable to sperm; (b) an unusually small cervical opening that prevents further progression of the sperm; and (c) an abnormal uterine position (retroverted uterus). In these cases, $\mathrm{AI}$ is a suitable aid to conceive. In the first instance, the sperm not having to pass through the vagina has a better chance of surviving. In the second and third instances, AI may be used to deliver the sperm to an advantageous position for fertilization, a position they otherwise might not reach on their own accord. 2

Furthermore, single women who wish to have children may also opt for AI. ${ }^{2}$

There are two types of AI, depending on the source of the sperm employed in the procedure: artificial insemination homologous (AIH) and artificial insemination heterologous/donor (AID). In $\mathrm{AIH}$, the sperm is collected from the male partner. While "H"'refers to the "husband", the male partner does not necessarily denote a legal husband. Rather, the male partner need only be the functional equivalent of a husband. ${ }^{2}$ On the other hand, AID uses sperm from a donor other than the "husband". AID is recommended in cases of azoospermia, severe oligospermia, or abnormal motility of the sperm when intracytoplasmic sperm injection (ICSI) peformed in conjunction with in vitro fertilization (IVF) is not feasible or has failed. ${ }^{3}$ AID also is recommended when the husband suffers from a neurological condition that makes ejaculation impossible or 
from a disease such as diabetes that makes him impotent. ${ }^{2}$

Furthermore, AID is recommended with a genetic condition that carries a high risk of transmission to the fetus, e.g. in autosomal recessive conditions such as Tay Sachs disease when the risk is $25 \%$ if both parents are carriers or in autosomal dominant conditions affecting the husband such as Huntington's disease when the risk is $50 \%$. In both cases, in order to prevent the unborn child from inheriting a genetic disorder, the couple may select sperm of a healthy donor to impregnate the ovum.

\section{Islamic Jurisprudence}

Islam means submission to the will of Allah de in all aspects of life. It aims at shaping both individuals and society in ways that will ensure that peace, contentment, and well-being may fill the world.4 The spirit of Islam is translated into practice through the codification of divine revelations to Prophet Muhammad a into instructions (prescriptions and proscriptions) that regulate our daily living, referred to as the sharia $a$ or Islamic Law. Shari $a$ is the epitome of the Islamic spirit, the most revered manifestation of the Islamic way of life, the kernel of Islam itself. ${ }^{5}$ The first four sources of the shari $a$, in descending order of importance, are the Holy Book (Qur'ān), tra-

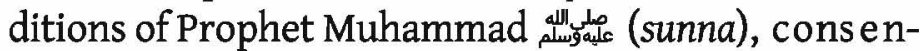
sus of the relgious scholars (ijm $\left.\bar{a}^{\prime}\right)$, and analogy (qiyās).

In Islam, the basic framework for such jurisprudence is the Qur'ān. But the Qur'ān, despite presenting a rich variety of specific rules and general principles, does not explicitly focus on every possible situation a Muslim may face. For cases not explicitly addressed in the Qur'ān, Muslims have to access the sunna, the traditions or hadiths of Prophet Muhammad allugiste as a secondary source of guidance. When the sunna also leaves open some questions of interpretation or application, Muslims have to seek guidance from learned Islamic jurists ('ulama') in the form of consensus (ijmä). The result would be in the form of a religious opinion, or fatwa , that provides specific guidance on the issues at hand. In certain situations, Islamic jurists also invoke analogies (qiyās) from the Qur'ān and sunna in order to clarify the rules relating to the issues raised.

If none of these methods provides a clear ruling, Muslim scholars must resort to ijtihād, which is the individual intellectual effort to make a judgment. 5

\section{Islamic View of AIH}

Procreation is a part of Allah's divine plan a

O mankind! Reverence your Guardian-Lord, Who created you from a single person, created of like nature his mate, and from them twain scattered (like seeds) countless men and women. ${ }^{6}$

\section{Another verse of the Qur'ān states:}

Wealth and progeny are the allurements of this world. ${ }^{7}$

Infertility is also a fact of life that must be confronted, and sometimes it can be overcome through treatment. It is reported that the Prophet said, "God has created disease and cure, and He made for each disease a cure. So seek cure, and don't seek cure through prohibited actions." 8 Therefore, couples can try to overcome their childlessness through treatment if it does not violate the principles of sharia.

As far as the shari $a$ is concerned, AIH is acceptable as long as it involves a lawfully wedded couple. It is not valid after a divorce. The view that AIH should take place between lawfully married couples is based on the fact that mating takes place within an authentic marriage contract according to Islam. The child to be born also has rights. He or she must be the legitimate offspring of a lawful couple. He or she should lawfully inherit the property of his or her parents. All these basic rights are ensured when the act is done during the marriage and not after the death of the man or after divorce takes place between the couple.

Regarding the use of the sperm of the dead husband kept in the semen bank by the wife to carry out $\mathrm{AIH}$, Sheikh 'Abd al-Khāliq Hasan al-Sharîf commented: "It is not permissible for the woman to use the frozen sperm of her husband after divorce or after his death. The issue is permissible only when both the husband and wife are living together (i.e. they are not divorced) and both of them are alive. Hence, it is not permissible for the ex-wife or the widow to use her husband's frozen sperm after his death or after divorce. The woman may face a very difficult situation as regards this, especially when she gets pregnant, while her husband is dead or she is divorced."9

The European Council for Fatwa and Research also expressed similar views in the following way: "It is permissible for the wife to use the sperm of her 
husband for fertilization unless she is divorced or the husband dies."9

Part of AI is the collection of sperm through masturbation. This brings up the issue of its permissibility. The majority of scholars declared masturbation as prohibited based on the following Qur'anic verses:

[the successful believers] who abstain from sex, except with those joined to them in the marriage bond, or (the captives) whom their right hands possess, for (in their case) they are free from blame, but those whose desires exceed those limits are transgressors ...10

However, masturbation would be permissible if it is done in order to collect sperm for AIH within the marriage bond. A basic tenet of Islam is that prohibited actions, if performed out of necessity, become permissible. So, AIH does not create any ethical problem vis à vis Islamic guidelines.

Two extreme views regarding AI originated from Roman Catholicism and liberal Western secular philosophy, respectively. It is completely prohibited in Catholicism even within a valid marriage. Conversely, liberal Western society allows it whether within the marriage bond or not.

Islam thus has presented a middle of the road solution. ${ }^{11}$

There should be absolute certainty that the sperm being injected into the uterus of the woman is her husband's. The abuse of AI procedures must be prevented and must be monitored through legislation. The procedure should be conducted under meticulous as well as safe laboratory conditions. All members of the team such as doctors, nurses, and technicians should be trustworthy and of strong moral standing.

\section{Islamic View of AID}

Dr. Yūsuf al-Qarādāwī, one of the most prominent contemporary scholars, opined that

Islam safeguards lineage by prohibiting adultery and fornication (zin $\bar{a})$ and legal adoption, thus keeping the family line unambiguously defined without any foreign element entering into it. It likewise prohibits what is known as artificial insemination if the donor of the semen is other than the husband.12
Using donor eggs or donor sperm is prohibited in Islam as it obliterates the lineage. So, Islam makes adultery a punishable crime in order to preserve the lineage. The Qur'ān mentions

It is He (Allah) who created mankind from water, then has $\mathrm{He}$ established the relationship of lineage and marriage for your Lord has power over all things.13

Not knowing the correct (biological) lineage may cause one to marry a half-brother, half-sister, or any other close relative with whom marriage is forbidden. These types of situations will cause harm, not only to the individuals involved, but in the long run to the society as a whole.

The famous jurist, Mustafa al-Zarqā, said that the AID does not fulfill the prerequisites of zina, and, therefore, the punishment of zinā is not applicable. AID may be subject to lesser penalties, however, at the discretion of the government. Therefore, although AID is not legally or morally zina, it is morally wrong and prohibited from the perspective of Islamic ethics.14 The prohibition will be much stronger if AID is used without the knowledge and consent of the husband, as it also involves deceit and destroys the trust (amanna) that is part of the marriage contract.

Moreover, although the outcome of AID is in reality an illegitimate child according to the shari $a$, the husband may nevertheless be considered the legal father, in which case the child has inheritance rights from both the mother and the father, based on the Hadith, "The child belongs to the [marriage] bed."15

In Islam, every person has the right to be the legitimate child of his or her parents. Even if the couple is agreeable, the right of the child to legitimacy is not theirs to tamper with.a

If the father knows that the child does not belong to him but to someone else, he may be reluctant about his duties and responsibilities. ${ }^{16}$

It is true that having a child is a blessing, but in order to have a child, we should not cross the limit.

aEditor's note: Also see Pollack D, Bleich M, Reid CJ, Fadel MH. Classical Religious Perspectives of Adoption Law. Notre Dame Law Review. 2004 Feb;79(2):693-753. 
It may be argued that the Western concept of procreative liberty makes it easy for the infertile couple to have children and the Islamic approach is very rigid and limits human freedom. While this is true, this procreative liberty creates significant problems for the resulting offspring. Children so conceived suffer emotionally.

The [offspring of donor insemination] are not seeking to be raised or supported by the donor fathers. Rathey, they pine for knowledge of, and connection to, the missing halves of their very selves. One adult offspring at a sperm-donor [Internet] group recently wrote: "We don't want money. . . . We have the fundamental questions that everyone has on growing up. Where did I come from? Who am I? Do I have their eyes, their noses, their hair?"17

Currently, there is an unresolved dispute whether to disclose the identities of sperm donors. Procreative liberty is ultimately doing harm to society by weakening family ties.

The axiology of Islam is not limited to short term benefit; rather, it addresses the longterm effects that will ultimately result in the greatest benefit to mankind. If it would allow AID, it would fulfill the temporary satisfaction of parenthood but ultimately would not be good for the child, the parents, or the society as a whole.

\section{Conclusion}

Islamic guidelines permit AIH provided that proper precautions are taken so that no foreign element other than the sperm of the husband is used. It prohibits AID for the greatest welfare of the society. A very coherent and logical form of social justice is reflected here. AID from the Islamic standpoint presupposes that goodness is not a narrow concept; the ontology of good bears an all-inclusive character. The Islamic prohibition of AIH is based on the fact that the longterm good is more beneficial than temporary satisfaction of desires.

\section{References}

1. Post SG. Reproductive technologies. In: Post SG, editor. Bioethics for students: how do we know what's right? New York: Macmillan Reference USA; 1998.

2. Munson R. Reproductive control: assisted reproduction and ethics. In: Munson $\mathrm{R}$ (editor). Intervention and Reflection: Basic Issues in Medical Ethics. 6th ed. Stamford: Wadsworth; 2000.

3. Teoh ES. Infertility: Finding the Right Solution. Singapore: Times Books International, 1987.

4. Maududi AA: The Islamic Concept of Life. In: http://www.islam101.com/sociology/conceptLife.ht m. Accessed on Feb. 24, 2007.

5. Syed IB. Ijtihad. In:http://www.irfi.org/articles/ articles_1_50/ijtihad.htm. Accessed on Feb. 24, 2007. 6. Glorious Qur'ān, Chapter 4, Verse 1.

7. Glorious Qur'ān, Chapter14, Verse 46.

8. Abū Dāwūd Sulaymān ibn al-Ash'ath al-Sijistānī. Kitāb al-sunan. Kitāb al-țibb. Bāb fī al-adwiyya almakrūha. Hadith 3874. Available from http://www.muhaddith.org. Accessed Feb. 25, 2007. 9. IslamOnLine.net. [homepage on the Internet]. Web site. Artificial Insemination from an Islamic Perspective. [Updated 29 Dec 2002. Accessed on 25 Feb 2007]. Available from http://islamonline.net/fatwa/english/FatwaDisplay .asp?hFatwaID $=76500$.

10. Glorious Qur'ān, Chapter 23, Verse 5-7.

11. Glorious Qur'ān, Chapter 2, Verse 143.

12. Yusuf al-Qaradawi. The lawful and prohibited in Islam. El-Helbawy K, Siddiqui MM, Shukry S (translators). Indianapolis, IN: American Trust Publications; 1982.

13. Glorious Qur'an, Chapter 25, Verse 54.

14. Muștafā Ahmad al-Zarqā. Fatāwā Mușțafā alZarqā. Makki MA (editor). 3rd ed. Damascus: Dār alQalam; $2004 \mathrm{AD} / 1425 \mathrm{AH}$.

15. Muhammad ibn Ismā'īl al-Bukhārī. Șahịh al alBukhārī. Kitāb al-buyū' (39). Bāb tafsīr al-shubuhāt (3). Hadith 1948. Available from http://www.muhaddith.org.

16. Anonymous: Islamic View on Artificial Insemination. In: http://www.imamreza.net/eng/imamreza.php?id=4 108. Accessed on Dec. 13, 2006.

17. Wolff J. Sperm Donor Ruling Could Open Door For Offspring (Final Edition). USA TODAY. 2004 Jun 15;A13. Available from: http://www.usatoday.com/news/opinion/editorials/2004-06-14-wolff_x.htm. 